\title{
Compromise Without Solution
}

EVERYBODY knows by now that an arbitration tribunal inquiring into a pay dispute can usually be relied on to split the difference between the two opposing sides. This, predictably enough, is what the public inquiry into the salaries of scientists in the British civil service has done (see page 594). Those who had been offered nothing are now to get an extra five per cent. Those who had been offered something, for practical purposes about ten per cent, will have to be satisfied with that. With masterly empiricism, the tribunal says that the award "seeks to apply the principle of fair comparison and pay research taking into account the special features of a scientific career in the civil service and the fact that the pay of the scientific grades has been determined hitherto by horizontal relativity" without saying why it considers that the arguments put forward by the Civil Service Department in the past few months were invalid, as the Institution of Professional Civil Servants has been claiming. Indeed, the tribunal has the gall to say that "the award should in no way be taken to prejudice future decisions about the unified grading of the scientific and other classes". In other words, the tribunal has casually discarded one of the principles used in previous inquiries like this but has neglected to suggest a replacement. Nobody can be blamed for reacting vigorously to this development. The Civil Service Department will have only itself to blame if the Institution of Professional Civil Servants now becomes a constant thorn in its flesh. Unhappily, even the institution is a long way from recognizing that the time has come to take a much more radical view of the framework within which professional scientists should be employed by the British government.

The most obvious difficulty is that the scientific civil service has become a genteel blind alley for a great many of those who work in it. This is the point that the Fulton commission made. In practice, it has been exceedingly difficult for civil servants who begin as scientists to become, in the course of time, administrators of a more conventional kind. A part of the reason, no doubt, is that many working scientists in the civil service prefer to stick to science-not all of them complain. But it is beyond dispute that for a great many people who would normally expect in other walks of life, in industry for example, to move sideways from research into administration, the present rules are cramping. It is true that the Civil Service Department has been looking for recipes for transforming the civil service along lines that might have been suggested by the Fulton commission and that, ironically, discussions on these have been in part held up by the pay dispute. In the meantime, however, it is plain that the very large proportions of people who have accumulated in the higher grades of the scientific civil service are a measure of the extent to which there are few ways out at the top.

What is to be done? The first thing to recognize is that to the extent that many professional scientists in the civil service value their professional connexions as much as their status in the hierarchy, there is a strong case for hoping that it should be made comparatively easy for them to leave the civil service for other kinds of work. In other words, there should be much easier machinery by means of which scientists in the civil service could contract out of the arrangements which are conventional. In particular, it should be much easier for them to take their pensions with them if they are so inclined. The simplest way of arranging this would be to arrange that the Civil Service Department would convert into cash or its equivalent the accumulated pension rights of somebody wishing to leave. To be sure, this might often mean that the civil service would lose many men of promise and attainment, but then the question arises what in any case is the civil service for? Is it really meant to be an organization primarily concerned with its own perpetuation? Or should it be more eager than it is to help spread its skill about the country? These and related questions are the ones which the Institution of Professional Civil Servants should now be asking. It would be a great misfortune if they become entirely lost in detailed quibbles about the most equitable way of comparing dissimilar kinds of careers.

\section{Years Aao}

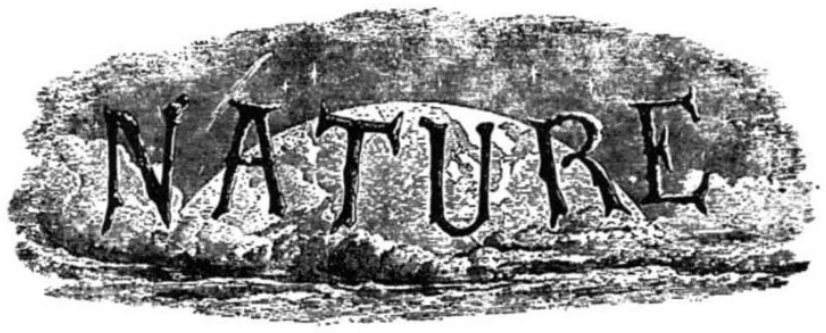

IN his last weekly return, the Registrar-General refers to the westward advance of Asiatic cholera as investing with more than ordinary interest Dr. Frankland's usual montbly report upon the quality of the metropolitan water supply. The water supplied by the New River and Kent Companies is again reported freest from organic impurity, that of the East London and Chelsea Companies the most impure. With reference to the advantage which would be derived from a general application of Dr. Clark's softening process to the London water supply, the RegistrarGeneral adduces the following valuable facts, which have been communicated by Mr. Robert Rawlinson, C.B., C.E. :--"The average daily water supply to the metropolis was $111,292,104$ gallons in June, and II2, 107,697 gallons in July. Now in each million gallons of these waters there is about one ton of bi-carbonate of lime, or $111 \frac{1}{t}$ tons in June and 112 in July. About two-thirds of this weight of lime or chalk would be removed by Dr. Clark's softening process-that is, in June 74 tons, and in July about 75 tons. In each year about 25,000 tons of useless lime would be removed from the metropolitan waters by the simple and easy process now in use at Canterbury." The Registrar adds: "This riddance of the foreign matter, which deprives water of some of its cleansing properties, is in itself an advantage ; but, besides this, the fine precipitate of chalk carries down with it suspended impurities and probably frees it from choleraic and other contagions. It is a most effective filtration." It is a comfort to know that the working classes are beginning to feel their strength. When that is put forward it is certain to be in the direction of sanitary and educational measures. The RegistrarGeneral appends to his report a concise sketch of the steps proper to be taken in view of the threatened epidemic.

From Nature, 4, 349, August 31, 1871 